\title{
HOUSE PRICES AND HOME OWNER SAVING BEHAVIOR
}

\author{
Gary V. Engelhardt
}

Working Paper No. 5183

\section{NATIONAL BUREAU OF ECONOMIC RESEARCH 1050 Massachusetts Avenue \\ Cambridge, MA 02138 \\ July 1995}

This paper was prepared for the NBER Conference on Public Policy and Housing Markets, Kiawah Island, SC, October 20-22, 1994. I would like to thank the Mellon Foundation, the Rockefeller Center for the Social Sciences at Dartmouth College, and the Federal Reserve Bank of Boston for research support, and Annamaria Lusardi, Christopher Mayer, Steven Venti, and seminar participants at the 1994 NBER Summer Institute, Dartmouth, and the NBER Conference for helpful comments. In particular, I thank Jesse Abraham, Jonathan Skinner, and especially Patric Hendershott for careful comments and suggestions. All errors are my own. This paper was prepared as part of the NBER Study on Housing Dynamics and was presented at the NBER Study Conference. Any opinions expressed are those of the author and not those of the National Bureau of Economic Research.

(c) 1995 by Gary V. Engelhardt. All rights reserved. Short sections of text, not to exceed two paragraphs, may be quoted without explicit permission provided that full credit, including () notice, is given to the source. 


\title{
HOUSE PRICES AND HOME OWNER \\ SAVING BEHAVIOR
}

\begin{abstract}
This paper examines the empirical link between house price appreciation and the savings behavior of home owners during the 1980s. The analysis uses household asset and debt data for a sample of under age sixty-five home owning households from the 1984 and 1989 waves of the PSID to construct changes in real household wealth as a measure of household saving behavior. Cross-time and cross-regional variation in housing market conditions are used to identify behavioral savings effects.

The empirical analysis suggests that the estimated marginal propensity to consume out of real housing capital gains is 0.03 for the median saver household. However, there is an asymmetry in the saving response to both total and unanticipated real housing capital gains. All of the savings offset comes from households that experience real housing capital losses. Households that experience real gains do not change their saving behavior. The existence of this asymmetry casts doubt on the power of changes in house prices to explain the time series path of saving in the U.S.
\end{abstract}

Gary V. Engelhardt Department of Economics Dartmouth College Hanover, NH 03755 


\section{Introduction}

Changes in the real value of housing wealth in the U.S. in the last twenty years have resulted in large changes in household balance sheets. Home owners in many areas experienced windfall gains in housing wealth in amounts far greater than the level of their existing financial and housing assets. Simple models of life-cycle saving behavior suggest that households might offset such real gains in housing through a reduction in non-housing saving. However, despite the fact that roughly two-thirds of American households own homes and housing is the single largest asset home owners hold, comparatively little research has been undertaken to examine the links between real housing capital gains and consumption and saving behavior, particularly at the household level.

This paper examines the empirical link between house price appreciation and the savings behavior of home owners during the 1980s, a period of rapid real appreciation regionally and declining household savings rates. Unlike previous studies that have used aggregate data or household data on food consumption, the analysis uses household asset and debt data for a sample of under age sixty-five home owners from the 1984 and 1989 waves of the Panel Study of Income Dynamics (PSID) to construct real changes in household wealth as a measure of household saving behavior. Cross-time and cross-regional variation in housing market conditions are used to identify behavioral savings effects.

The empirical analysis indicates that the estimated marginal propensity to consume out of real housing capital gains is 0.14 for the mean saver household and 0.03 for the median saver household. Whereas these results support those of Skinner (1993), there is no firm 
evidence of a positive offset as found by Hoynes and McFadden (1994). Differences in findings between these studies can be attributed to differences in the measure of saving and econometric methods employed. In addition, the empirical results indicate an asymmetry in the saving response to both total and unanticipated real housing capital gains. All of the savings offset comes from households that experience real housing capital losses. Households that experience real housing capital gains do not alter their saving behavior. The existence of this asymmetry casts doubt on the power of changes in house prices to explain the time series path of saving in the U.S.

The paper is organized as follows. Section 2 briefly discusses the manner in which real housing capital gains may affect savings behavior. Section 3 discusses previous empirical work on the effect of house prices on saving behavior. The new empirical analysis is laid out and findings discussed in section 4 . There is a brief conclusion.

\section{Saving Response to Housing Gains}

Real house price appreciation can have a number of possible effects on household saving behavior. In a simple orthodox life-cycle model with certainty, saving is undertaken to fund consumption during retirement. Real housing capital gains would result in a decrease in nonhousing savings and substitute directly for the non-housing wealth in financing retirement consumption. A number of assumptions must be true to obtain this result.

First, in the absence of liquidity constraints, the real housing capital gains must be unanticipated and perceived to be permanent by home owners. Transitory gains would have 
no effect on consumption and saving decisions, whereas the effects of expected housing capital gains would have already been smoothed into consumption and have no effect on behavior at the time the gains occur.

Second, housing wealth must be fungible with other forms of wealth, i.e., households must not treat housing as an asset differently from other assets, such as stocks, bonds, etc. Thaler (1990) argues that households have "mental accounts," one of which is for housing. Unlike the orthodox life-cycle model of saving, assets held in one mental account (such as "retirement" saving) are not fungible with assets in other accounts (such as "housing"). Thus, households will not offset real capital gains from assets such as housing with reductions in holdings of other assets. However, portfolio diversification benefits argue against mental accounts.

Third, households must be able to spend their real housing capital gains. This could be accomplished, in theory, by the existence of financial vehicles such as reverse mortgages and/or second mortgages. Manchester and Poterba (1989) study the link between second mortgages and saving behavior. They found that second mortgages grew rapidly in popularity in the 1980s and that every dollar of second mortgage borrowing is associated with a seventy-five cent reduction in household net worth. In contrast, there is little evidence of reverse mortgage activity (e.g., Venti and Wise (1991) and Mayer and Simons (1994)). This suggests that there is either little supply of reverse mortgage vehicles by financial institutions and/or little demand by the elderly to spend down their accumulated housing capital gains. The other way a household can spend real capital gains is through the sale of the home. 
However, in order for gains to affect saving in this manner, moving costs-both psychic and monetary-must not be exorbitant, and many studies suggest that moving costs may be high (e.g., Venti and Wise (1984)).

Fourth, there must not be a bequest motive or altruism toward future generations. The existence of a bequest motive allows for the possibility that housing gains are not consumed but given to others: households experiencing large real housing capital gains might not save less in non-housing forms, but pass the gains through to their children (a younger generation) who now face higher lifetime housing costs. Skinner (1989) formulates a 55period overlapping generations life-cycle saving model with housing appreciation. He finds that the aggregate saving rate is only about half as responsive to real housing appreciation when there is a bequest motive to future generations than in a life-cycle model without bequests. In addition, Engelhardt and Mayer (1994) find that about one-in-five first-time home buyers receives help from relatives in the form of a gift or loan in funding the down payment on the first home. Conditional upon receiving such help, the amount of the transfer is large-roughly half of the down payment on average.

If any of these assumptions do not hold true, then the life-cycle model does not predict that households necessarily will reduce real non-housing saving with respect to real housing capital gains. In addition, even if all of these conditions hold and there is a saving offset, the annual offset predicted by a life-cycle model is not necessarily dollar-for-dollar. Skinner (1993, 1994) argues that the predicted marginal propensity to consume from one dollar of housing capital gain should be based on the present value of the real gain discounted back 
from the future date of sale of the home. In his example (Skinner (1994)), the present value of a $\$ 100,000$ gain realized 30 years later is worth only about $\$ 42,000$ at a three percent discount rate, not the full $\$ 100,000$. In addition, the value of the gain must be calculated relative to the price of housing after the gain. For example, a household that receives a $\$ 100,000$ gain is not $\$ 100,000$ richer if the cost of housing in its locality has risen along with its home. In order to further determine the extent to which saving gains may be spent, Skinner (1993) constructs a simple life-cycle model of saving with no moving costs and, given plausible parameter values, calculates the predicted marginal propensity to consume from housing capital gains to be 0.025 . $^{1}$ The addition of large moving costs reduces this predicted MPC to 0.014 .

\section{Previous Findings from Micro Data}

While studies of house prices and saving using aggregate data-such as Bhatia (1987), Peek (1983), Hendershott and Peek (1985a, 1985b), and Skinner (1993)-consistently have shown evidence of a strong link between house prices and saving behavior, the microeconometric studies for home owners generally have not shown an effect. In the first main study of home owners using micro data, Skinner (1989) examines the effect of real house price levels-as opposed to appreciation-on the real consumption behavior of a sample of home owners

\footnotetext{
${ }^{1}$ Nakagami and Pereira (1991) discuss the effect of house price appreciation on home owner trade-up decisions in detail, but do not consider the effect of housing appreciation on non-housing consumption and saving decisions.
} 
drawn from the $P S I D .^{2}$ Estimates of a household-level consumption function suggest that the marginal propensity to consume from housing wealth is 0.06 ; i.e., total consumption is six cents higher for every one dollar increase in house value. However, there is no effect of house value on consumption when controlling for household fixed effects in consumption. ${ }^{3}$

Skinner (1993) uses the 1984-89 PSID asset and debt data to study the effect of changes in real housing wealth on real non-housing savings. He uses a sample of home owning households that did not move between 1984 and 1989 and employs a measure of real housing capital gains based on differences in households' self-reported home value. Estimates suggest that for the median household aged 45 years and older, one dollar of ex post real housing capital gains decreases non-housing savings by 2.8 cents.

Rather than using the self-reported home values from the PSID, Hoynes and McFadden (1994) match house price data from 112 metropolitan areas obtained from the American Chamber of Commerce Researchers Association (ACCRA) to households in the PSID. Their empirical estimates imply that an increase in the ex post rate of real house price appreciation of one percentage point leads to an increase in real savings rates of 0.26 percentage points.

\footnotetext{
${ }^{2}$ The PSID gathers data on household food expenditure only for most years. In general, except for information on commuting costs and alcohol and cigarette expenditures gathered from 1968-72, there is no information on other classes of non-liousing expenditure. However, information on the number of automobiles, heat and utilities expenditures is given for many years of the panel. Skinner forms a measure of total household consumption by first regressing total consumption on food expenditure, heat and utilities expenditure, and number of automobiles in the Consumer Expenditure Survey (CES) and then uses the estimated coefficients from this regression to predict total household consumption in the PSID. Details of this consumption imputation method are outlined in Skinner (1987).

${ }^{3}$ Skinner (1989) controls for fixed effects by subtracting off the houselold's cross-time mean consumptionrather than first-differencing the data-which may not be consistent with a rational expectations approach to modeling consumption behavior. In addition, Skinner's sample contains households that did not move and, thus, are the most likely to be affected by changes in house values in their consumption decisions. He controls for possible selection bias from excluding movers and finds no evidence of selection bias by examining solely the consumption of stayers.
} 
This effect is statistically significantly different from zero.

This result goes strongly against the simple theoretical prediction as well as previous findings from aggregate data. The fact that these two studies yield opposite conclusions, while using the same household survey, is intriguing. Potential reasons for the divergence in findings include different measures of saving and housing capital gains and differences in sample selection.

\subsection{Measuring Saving Through Wealth Changes}

Household saving is notoriously difficult to measure. Typically, when using household data on consumption, such as the Consumer Expenditure Survey, saving is defined as the residual between after-tax income and consumption. Saving for a given period of time also can be measured as the real change in wealth from the beginning of the period to the end of the period.

Changes in wealth can occur for two reasons. First, a portion of current income is not consumed and used to purchase assets. This is typically thought of as saving, and what I will term "active" saving. Second, real wealth can increase if there are real capital gains on existing assets in the household's portfolio that are not consumed. This is what I term "passive" saving, since it requires no effort on the part of the household. Skinner (1993) uses a measure of real active saving based on the 1984-89 change in non-housing wealth net of passive capital gains to assets. On the other hand, Hoynes and McFadden (1994) use a measure of real saving that includes both passive and active saving, specifically, the 1984-89 
change in real non-housing wealth inclusive of passive capital gains to assets.

A potential drawback of the latter measure is that passive gains in housing wealth may be correlated with passive gains in non-housing wealth. For example, households in areas experiencing housing booms may also experience increases in business equity due to the increase in economic activity fueling the boom. This problem is greater for business equity whose value is likely determined in local markets than for passive gains in stocks or bonds traded on national markets. In addition, simple theory suggests that households may change their saving behavior in response to passive non-housing gains, which implies that these passive gains should appear as an explanatory variable and not as part of the dependent variable.

\subsection{Measuring Housing Capital Gains}

Real housing capital gains also are difficult to measure. One possible conceptual measure is the change in the real value of the household's home, where the value is measured by the transaction price the house (or a comparable house) would garner if sold at the time of the $P S I D$ interview and deflated into real terms. Unfortunately, this ideal measure is not available.

One alternative measure is based on the household's self-reported home value. Each year the PSID asks what the home owner believes the value of the house to be if presently sold. ${ }^{4}$ The household's reported value of the home in 1984 and 1989 can then be used to construct a

\footnotetext{
${ }^{4}$ The actual question is stated as "Could you tell me what the present value of your (house /apartment (farm) is - I mean about how much would it bring if you sold it today?"
} 
measure of housing capital gains. A conceptually consistent measure of housing capital gains would be a measure of passive gains, i.e., from market-wide increases in prices. However, a household's home value may increase through additions and/or repairs to the structure, even if market-wide prices are stable. Therefore, a measure of passive housing capital gains for a household should net out the value of additions and repairs to the property. Skinner (1993) uses the real change in home values between 1984 and 1989 less the real value of additions and repairs done to the structure in the $1984-89$ period. I employ the same measure in the empirical analysis below.

There is an advantage to using self-reported housing values: what a household believes its home to be worth and how great it perceives its unrealized real capital gains to be should be the driving force in consumption and saving decisions. In addition, a measure of housing capital gains based on self-reported home value can be calculated for households regardless of geographic location.

However, this measure has disadvantages as well. First, capital gains cannot be calculated accurately for households that move because some households may be trading-up in the market to larger, and therefore higher priced, homes. Trade-up households would appear to have positive capital gains, even if they were in a stable housing market. Second, mismeasurement of the home value-and, therefore, capital gains-may bias the estimated coefficient on real housing capital gains in the savings regressions. In a study of the accuracy of home owners' reported house values, Goodman and Ittner (1992) compare home owners' reported house values to subsequent sale values using the 1985 and 1987 American Hous- 
ing Surveys (AHS). They find that home owners systematically overestimated the value of their home by ten percent relative to its subsequent sale value. In addition, they find no evidence that the reporting errors are correlated with characteristics of the structure, local housing market conditions, or income and demographic characteristics of the home owner. This suggests that reporting errors associated with self-reported house values will not bias the parameter estimates on variables other than the housing capital gains variable. However, the estimated parameter on housing capital gains will be biased toward zero due to the measurement error, which makes it harder to find evidence that there is a significant negative relationship between housing capital gains and non-housing saving.

Another alternative measure of housing capital gains is one computed as the change in the average (or median) house price in the locality in which the household resides, be it an SMSA, county, municipality, or neighborhood. Hoynes and McFadden (1994) use real rates of appreciation by SMSA constructed from the ACCRA metropolitan house price indices. These data are price indices for a "standard 3 bedroom, 2 bath one family house suitable for a mid-management level owner." ${ }^{5}$ The data for the indices are obtained quarterly for the above type of house from surveys of homebuilders, bankers, and appraisers. Because the ACCRA price indices are for a particular type of home, they may not be representative of all homes trading in the market. Indeed, Poterba (1991) and Mayer (1993) have found evidence that different homes appreciate at different rates during the real estate cycle, and Case and

\footnotetext{
${ }^{5}$ From p.11 of Hoynes and McFadden (1994), from which they cite American Chamber of Commerce Researchers Association (1992). Hoynes and McFadden (1994) describe the data and their construction in more detail. For a detailed discussion of the ACCRA and other local house price series, see Haurin, Hendershott, and Kim (1991).
} 
Mayer (1994) provide evidence of substantial variation in appreciation rates across localities within metropolitan areas.

In addition, the ACCRA price indices may not be the best indices to use because of a substantial number of missing values for many important metropolitan areas. The ACCRA data are collected quarterly, but many cities do not report prices for every quarter of the year. The PSID interviews are given in the first quarter of the year. According to the ACCRA data, there are missing values in the price data for either 1984:1 or 1989:1 for the following metropolitan areas: Kansas City, Baltimore, Los Angeles, San Francisco, Atlanta, Dallas, Las Vegas, Newark, New York, Philadelphia, Pittsburgh, Charleston, Seattle, Milwaukee, Orlando, Minneapolis, and Cincinnati. One solution to this missing data problem is to assign price data from "nearby" quarters to the interview quarter. Using a three quarter window for the price data of 1983:4-1984:2 for the 1984 PSID interview and 1988:4-1989:2 for the 1989 PSID interview yields additional complete price data only for Las Vegas, Pittsburgh, and Orlando. Moreover, there are no price data for 1984 and 1989 for Boston, Detroit, Providence, Chicago, and Honolulu.

\subsection{Differences in Sample Selection}

Sample selection. is another source of differences in results between the previous studies. Hoynes and McFadden must throw out households in areas where the ACCRA price data are missing. Indeed, the authors report that of the 4,360 observations available after implementing their sample selection rule, 1,666 observations, or $38.2 \%$, are dropped for this 
reason, while no observations are dropped in Skinner's study. Furthermore, Skinner draws a sample of home owners, whereas Hoynes and McFadden draw a sample of both renters and home owners. The inclusion of renters in the sample may greatly affect the estimated savings offset, for renters could be predicted to behave differently from home owners in response to an increase in home prices. For example, increases in home prices may reduce the affordability of home ownership and thus the number of renters saving for a home. However, increases in house prices may increase the saving of those households still wishing to own, either because the required down payment amount rises with house prices, or a potential home buying household would like to buy sooner rather than later in a rising market so as to capture a larger housing capital gain as an owner. ${ }^{6}$ Both of these effects would lead theoretically to increases in saving among renters. ${ }^{7}$ Therefore, it is possible that the saving behavior of renters as a group is positively correlated to the rate of growth of house prices, and that this response offsets any (potential) negative response by home owners.

The two studies also differ in the treatment of households that move between the 1984 and 1989 interviews. Hoynes and McFadden analyze movers and stayers, while Skinner's sample includes only those households that do not move in the $1984-89$ period. His estimates suffer from potential sample selection bias if shocks to house prices affect both savings and mobility decisions, which seems plausible.

Finally, it is well known that the distribution of saving and wealth is highly skewed

\footnotetext{
${ }^{6}$ Sheiner (1995) finds a positive relationship between renters' wealth accumulation and house prices.

${ }^{7}$ Another possibility is that of a recognition effect in savings behavior whereby households see house prices rising and realize that if they do not start saving now, they may never be able to own a home in the future. There were reports about this type of saving behavior circulating in the popular press in California in the late 1980's.
} 
toward the upper end of the wealth distribution (e.g., Avery and Kennickell (1991)). In particular, many households have very low or zero saving rates and little wealth, whereas high wealth households do substantially more saving; hence, outliers can have potentially important effects on estimates of the saving offset.

The two previous studies take different approaches in handling outliers. Hoynes and McFadden attempt to eliminate the influence of outliers on the empirical estimates by trimming off 2.5 percent of the observations from each tail of the sample saving distribution and then using the ordinary least squares estimator to estimate the savings offset. Their parameter estimates are interpreted with respect to the mean saver. Alternatively, Skinner uses the Least Absolute Deviations (LAD) estimator of the median, which is robust to outliers. ${ }^{8} \mathrm{Be}-$ cause mean saving is greater than median saving the estimated saving offset from housing capital gains using mean regressions is expected to be greater (in absolute value) than from median regression.

\section{Empirical Analysis}

I follow Skinner (1993) and select a sample of home owning households from the PSID in 1984 that did not change residences in any of the years in the 1984-89 period. In order to avoid many issues concerning the housing and saving behavior of the elderly, I exclude households with heads age 65 and over in 1984. Because major changes in family composition, such

\footnotetext{
${ }^{8}$ The LAD estimator of the median chooses parameter estimates to minimize the sum of the absolute value of the deviations, as opposed to minimize the sum of the squared deviations as OLS does.
} 
as divorce or widowhood, also can alter dramatically a family's wealth position, I include only those households that did not experience such a change during the 1984-89 period. Households with stable marital status and headship, but which added or lost a family member (e.g. a new child is born or a child moves out) are included in the sample, but controlled for in the empirical specification. Finally, I exclude households that report home values and/or incomes of less than $\$ 2,000$ and $\$ 1,000$, respectively.

The empirical analysis uses two measures of real saving. The first, active saving, is the difference in non-housing wealth in the form of automobiles, cash, bonds, and non-mortgage debt between 1984 and 1989 plus the net additions to business equity, stocks, and pension annuities between 1984 and 1989, less the total amount of inheritances received between 1984 and 1989, and the net worth of individuals moving into the household plus the net worth of individuals moving out of the household from 1984 to $1989 .^{9}$ The CPI is used to deflate

\footnotetext{
${ }^{9}$ This is the measure of active saving provided in the PSID and is the one employed by Skinner (1993). Because the sample has been limited to households that experienced no major changes in family composition in the 1984-89 period, the net worth of movers in and movers out will not heavily influence this measure of saving. In 1984, the PSID asked households to report the amount of assets they held in cash, stocks, bonds, automobiles, equity in a business or farm, owner-occupied housing, and other (non-owner-occupied) real estate. The "cash" category includes assets held in checking accounts, savings accounts, certificates of deposit, Individual Retirement Accounts (IRA), 401(k)'s, etc. The "stocks" category includes shares in mutual funds. The "bonds" category includes the value of bonds, insurance policies, and collectibles, such as art. Other or non-occupied real estate is comprised of both rental property and second or vacation homes. The household also was asked to report both total mortgage and non-mortgage debt. Mortgage debt is the sum of outstanding principal on both the first and any second mortgages. Together, these asset and debt measures combine to form the household's net worth. In 1988, households were asked the following question "Suppose you (and your family living there) were to sell all of your major possessions (including your home), turn all of your investments and other assets into cash, and pay all your debts-would you have something left over, break even, or be in debt? How much would you have left over?" The PSID lists the response to this question as a measure of net worth. The households, however, are not asked to itemize these assets and debts in 1988. Thus, I do not use the 1988 measure of net worth in any of the wealth change calculations in this paper. However, the PSID does not ask enough detailed questions to determine the value of pension and social security wealth, so that change in wealth measures using this data are net of pensions and social security. In 1989, the household was again asked to report its balances for the above asset and debt categories. In addition, detailed questions were asked about the net additions (contributions net of withdrawals) to wealth in the form of business equity, stocks, and pension annuities.
} 
all nominal values in to real values. The second measure is the change in real non-housing wealth between 1984 and 1989.

Table 1 provides sample statistics for all of the variables used in the empirical analysis. All sample statistics are calculated using the 1989 family weights from the PSID. All dollar figures are in real 1984 dollars and all employment, education, and demographic variables are as of 1984 . The average value for the measure of active saving is $\$ 28,078$. Active saving is very skewed, however, with the median value equal to $\$ 8,211$.

The measure of real housing capital gains used in this paper is the difference in real self-reported home value in 1989 and 1984 less the real value of additions and repairs made by the household during the 1984-89 period (Skinner (1993)). Table 1 reports the mean and median value of these calculated real housing capital gains. The mean gain is $\$ 9,701$; but the median gain is actually negative, $-\$ 1,484$. Table 2 shows calculated real housing appreciation by state during the 1984-89 period based on the PSID housing values for a selected number of states. The dollar value of capital gains is given in column 1 . It varies from $\$-21,310$ in Colorado to $\$ 77,926$ in Massachusetts. Column 2 gives the average five-year rate of real appreciation in each state, and column 3 expresses these five year rates as equivalent one year rates. On average, households in sixteen of the twenty-eight states shown experienced real housing declines during the 1984-89 period. Households in California and the Northeast corridor experienced rapid housing gains. Column 4 expresses the real housing gains as a percent of household income during the same five year period. Both the positive and negative gains experienced by some households were substantial relative to income. In Massachusetts, 
for example, the real gains were more than forty percent of five year income.

\subsection{Basic Empirical Results}

Let $S_{\mathrm{i}}$ be the saving of household $i$ during the 1984-1989 period. Then the basic econometric specification can be written as

$$
S_{i}=\beta x_{i 84}+\gamma \Delta H_{i}+\alpha_{1} Y_{i 84}+\ldots+\alpha_{5} Y_{i 88}+u_{i}
$$

i.e., both measures of saving just described are modeled as a function of the real housing capital gains between 1984 and 1989, $\Delta H_{i}$, and income, $Y$, earned in each of the years between 1984 and $1989 .{ }^{10}$ In order to control for possible household heterogeneity in saving behavior, I include a vector of demographic variables, $x_{\mathbf{i} 4}$ : the head of household's age, age squared, and dummy variables for the head's race, marital status, number and ages of children, and education. In addition, because employment status and type of employment may affect saving behavior-in particular with respect to changes in business equity-I include dummy variables for whether or not the head and spouse of the household were employed or were self-employed in $19844^{11}$

A dummy variable for minor change in family composition is included in the specification;

\footnotetext{
${ }^{10}$ The PSID interview is conducted in the spring of each year. For the 1989 interview, information was asked about household assets and debts as of the interview date. However, the income information from the interview is asked about the previous calendar year, which would be 1988 income for the 1989 interview. Therefore, the relevant income measure to include in the specification is income earned from 1984 through 1988.

${ }^{11}$ Because income and employment status are highly collinear, these variables have little effect in the estimated specifications presented below. Specifications were estimated with employment variables dated at 1989 rather than 1984, but this change made no difference in the estimation results.
} 
it equals one if the family experienced a change in family composition that involved neither the head nor the spouse and zero otherwise. According to the sample statistics provided in Table 1, forty-eight percent of the sample households experienced a minor change in composition in this period.

\subsubsection{Does the Measure of Saving Matter?}

Table 3 gives the baseline empirical estimates for this specification using mean regression. ${ }^{\mathbf{1 2}}$ The dependent variable for column 1 is the measure of real active saving described above. The explanatory variable of interest is real housing capital gains. The estimation results in column 1 suggest that real household non-housing saving is inversely related to real housing capital gains. The estimated coefficient, interpreted as the estimated marginal effect of housing capital gains for the mean saver, implies that a one dollar increase in real housing capital gains results in a 14.2 cent reduction in real saving. This effect is significantly different from zero. This result is consistent with magnitudes found by Bhatia (1987), Hendershott and Peek (1985a, 1985b), and Peek (1983) in aggregate data.

In column 2, I employ the second measure of real saving: the change in real non-housing wealth including passive non-housing gains. This measure is akin to that used by Hoynes and McFadden (1984). The mean regression results here suggest that for every one dollar of real housing capital gains there is a one cent increase in the level of real non-housing wealth,

\footnotetext{
${ }^{12}$ The findings reported below are robust with respect to different specifications of the saving equation and the manner in which real incone in the 1984-89 period enters. In particular, both mean and median regressions using the specification of McFadden and Hoynes (1994) - in which real saving enters as a rate (out of 1984-89 income) and real housing capital gains enter as a rate-suggest there is a negative saving offset from real housing capital gains when real active saving is used as the measure of saving.
} 
which is not significantly different from zero. That is, evidence of a negative offset exists only when a measure of active saving is used. The difference in the measure of saving used seems to explain much of the difference in the findings of Skinner (1993) and Hoynes and McFadden (1994).

\subsubsection{Mover-Stayer Selection Bias}

Given that the sample contains households that did not move in the 1984-89 period, there is a possible sample selection bias on the estimated saving offset. In columns 3 and 4 , I reestimate the specifications from columns 1 and 2 with selection corrections. In order for these new specifications to be identified, there needs to be exclusion restrictions; i.e., there must be at least one variable in the mover-stayer selection probit that does not appear in the saving specification. Because the saving equation is defined from 1984-89, anything in the household's information set as of the 1984 interview is valid as an excluded variable.

In each interview the PSID asks the whether or not the household expects to move in the next twelve months. If the household answers yes, then the household is asked to indicate the likelihood of such a move: low, moderate, or high. As exclusions, I construct variables that interact whether the household expects to move with the likelihood of such a move. In addition, I use the household's mobility history from 1968 to 1983 to construct the length of time the household has lived in its current residence. The first-stage probit includes these variables along with household income in 1982 and 1983 and the demographic variables from the saving equation. ${ }^{13}$

\footnotetext{
${ }^{13}$ The pseudo $R^{2}$ from the probit is 0.12 and the $\chi^{2}$ statistic for the test of the null hypothesis that all the
} 
The results in columns 3 and 4 of Table 3 indicate that any mover-stayer selection bias does not affect the estimated saving offset. The offset is 13.6 cents on the dollar for real active saving. It is still no different than zero using the change in real non-housing wealth as the dependent variable.

\subsubsection{Mean vs. Median Regression Results}

To examine the effects of trimming outliers on the empirical estimates, I provide OLS estimates of the saving offset on my PSID sample after trimming off 2.5 percent of the observations from each tail of my sample distribution. These results are presented for both measures of real saving in columns 5 and 6 of Table 3, respectively. For real active saving, a simple comparison of the estimates of the saving offset in column 1 (untrimmed) versus column 5 (trimmed) indicates that trimming greatly reduces the estimated negative offset from 14 cents to 3 cents (i.e., raised the coefficient by 11 cents). In fact, the estimated saving offset of 3 cents in column 5 is not significantly different from zero. When the change in real non-housing wealth is explained, the estimate of the saving offset in column 2 (untrimmed) is increased by 6 cents in column 6 (trimmed). Moreover, the estimated saving offset in column 6 now is positive and significantly different from zero.

The comparison of results using mean regression on the untrimmed and trimmed data is striking. Equally important, the rather arbitrary choice of where to trim the tails of the distribution can dictate the empirical estimates because the distributions of both real active

coefficients in the first stage probit are jointly equal to zero is 260.2 ; the full results are available from the author. 
saving and the change in real non-housing wealth are not symmetric. ${ }^{14}$ In particular, both saving measures have relatively short left-hand tails, because one cannot dissave more wealth than one starts with in 1984 . This is not the case for the right-hand tails of the distribution, which are relatively long. If the distribution of the dependent variable is not normal and symmetric, then trimming the tails of the distribution can greatly affect mean regression estimates.

Median regression results are given for the full sample of 1365 in columns 1 and 2 of Table 4. The estimated saving offset from housing capital gains for the median saver is negative and significantly different than zero, and 2.4 cents for every dollar of gain. This is substantially smaller than the estimate of 14 cents for the mean saver from above.

Therefore, one important difference in the results of Hoynes and McFadden (1994) and Skinner (1993) may be due to the treatment of outliers and the choice of econometric estimator. Because the the saving and wealth distributions are so skewed and mean regressions are so sensitive to the treatment of outliers, the rest of the empirical results in the paper will be presented using median regressions.

\subsection{Controlling for Other Influences on Saving}

Households that receive real passive capital gains to non-housing assets such as stocks and business equity may, in theory, reduce their saving in the same manner as a real housing

\footnotetext{
${ }^{14}$ OLS estimation on the sample of data with 5 percent of the observations trimmed from each tail yielded positive and significant (only at the 10 percent level of significance) saving offsets from housing capital gains. However, the magnitude of the estimate was only 3 cents.
} 
capital gain. Shocks to the value of non-housing assets also may be correlated with shocks to the housing market as described above, which suggests that omitting passive capital gains on non-housing assets may have biased previous estimates of the saving offset. Therefore, a measure of real passive capital gains in stocks and business equity is included in the specification in column 3 of Table 4 . The real amount of inheritance received by the household in the 1984-1989 period is included as well. These estimates imply that real active saving is reduced by 4.2 cents from every dollar of real housing capital gain.

The results also suggest that households do not offset real non-housing capital gains by reducing saving. Rather, saving actually increases. Bosworth, Burtless, and Sabelhaus (1991) and Avery and Kennickell (1991) also find this result. One potential explanation for this result is that most households in the sample do not hold stocks or business equity in their portfolios. In fact, the wealthier the household the more likely it is to own stocks and have equity in a business. This suggests that the households that received these gains simply are wealthy households. Wealthy households may have very different motives for saving than households in the middle and lower parts of the income and wealth distributions, e.g., stronger bequest motives. Alternatively, capital gains to business equity may not be spent down if cashing out the gains implies some loss of control over a partially-or wholly-owned business. In addition, the results imply a large effect of inheritances on saving behavior: saving is reduced by 50 cents for every dollar of inheritance received..$^{15}$

\footnotetext{
${ }^{15}$ Controlling for the level of non-housing wealth in 1984 or total wealth in 1984 did not affect the results. In other unreported specifications, $I$ included a dummy variable for whether or not the household took out a second mortgage between 1984 and 1989. The results suggest that households with second mortgages reduce saving by approximately $\$ 5,300$. This finding is consistent with Manchester and Poterba (1989), but difficult to interpret because second mortgages may reflect, not explain, dissaving.
} 


\subsection{Is There an Asymmetry in Response to Housing Gains?}

In column 4 of Table 4, I test to see if home owners' real active saving decisions respond symmetrically to real gains and real losses. ${ }^{16}$ These results are striking. There is no significant inverse relationship between real active saving and real housing capital gains. Instead, the behavioral response exclusively comes from households that experienced real housing capital losses: the estimated marginal propensities to save to offset real housing capital losses is about 0.35 .

One potential explanation for this result is that households with high loan-to-value (LTV) ratios in 1984 that experienced real housing capital losses increased real saving in order to avoid becoming "locked into" their homes. That is, a real capital loss may have wiped out the basis for a down payment on another home, had the household wanted to move. To test whether the asymmetric response is driven by high LTV households, in column 5 of Table 4, I include an interaction between real housing capital losses and the 1984 LTV. The parameter estimates suggest that a ten percentage point increase in LTV for households receiving real capital losses results in an additional six cent increase in real saving. This effect is significantly different from zero. ${ }^{17}$ However, the estimated parameter on the real housing capital loss variable shows that a significant part of the asymmetric response cannot be explained by LTV.

A second explanation is that based on housing appreciation of the 1970s, most households

\footnotetext{
${ }^{16}$ Mean regressions yielded similar results and are available from the author.

${ }^{17}$ Alternative specifications where real capital losses are interacted with a dummy variable for whether the household had an LTV of 90 percent or greater yielded similar, but somewhat statistically weaker, results. In addition, there is no evidence that the asymmetric response is related to the age of the household.
} 
in the 1980s may have expected positive real appreciation (Skinner (1993)). The households that actually experienced positive appreciation had anticipated those gains and thus they had no behavioral saving response to the change in house prices. However, households that experienced real losses were surprised; and thus adjusted their saving behavior.

In Table 5, I present median regression results where real housing capital gains are split into gains and losses but are unanticipated. The columns incorporate five different measures of unanticipated capital gains. As the bases for versions 1 and 2, rather than attempting to predict five-year capital gains-which is difficult given the large amount of economic information revealed to a household during a five-year period-I predict one-year capital gains for the 1984-85 time period using variables in the household's information set as of the 1984 interview as instruments. The residuals from this first-stage regression, which are measures of the unanticipated capital gains for the 1984-85 period, are then multiplied by five to form a five-year unanticipated gain. ${ }^{18}$

More precisely, Version 1 uses the household's 1983-84 housing gain, the household's home value in 1984, the number of rooms in the home, 1982 and 1983 income, and the demographic variables from the saving equation as instruments to predict the 1984-85 housing gain. The work of Case and Shiller $(1988,1989)$ suggests that lagged gains may predict future gains. The lagged income and demographic variables are intended to proxy for potential neighborhood characteristics which are not observed in the PSID. For example, households with young children may live in areas where school quality and certain local public ser-

\footnotetext{
${ }^{18}$ This is accomplished with the loss of only 125 observations, which were mover households in 1983.
} 
vices are important determinants of house prices and appreciation. Dummy variables for black and Hispanic households may proxy for households living in predominantly minority neighborhoods which historically have had much lower appreciation rates than similar white neighborhoods.

The empirical estimates using version 1 unanticipated gains indicate that real active saving displays a significant asymmetry in response to unanticipated gains and losses. In particular, home owners seem to only respond to losses: for each dollar of real loss, real active saving increases by 4 cents. The p-value for the test of symmetry between the coefficients on real gains and real losses for version 1 is 0.089 and indicates that the null hypothesis of symmetric response can be rejected.

Version 2 uses the same instruments as version 1 plus the lagged level and rate of change of the unemployment rate in the household's county of residence to proxy for county-specific economic conditions that may be reflected in future house prices. ${ }^{19}$ The empirical estimates using version 2 unanticipated gains also indicate that real active saving displays a significant asymmetry in response to unanticipated gains and losses. In particular, for each dollar of real loss, real active saving increases by 3.6 cents. The p-value for the test of symmetry is 0.005 and indicates that the null hypothesis of symmetric response can be rejected.

Alternatively, version 3 uses the household's 1979-84 housing gain, the household's home value in 1984, the number of rooms in the home, 1982 and 1983 income, and the demographic variables from the saving equation as instruments to predict the 1984-89 housing gain. How-

\footnotetext{
${ }^{19} 239$ observations are lost relative to version 1 due to missing county unemployment data.
} 
ever, housing gains from the 1979-84 period can only be calculated for those households in the sample that did not move in the 1979-84 period. As a result, the empirical estimates using version 3 unanticipated gains are calculated on a much smaller sample of 794 observations. The empirical estimates using version 3 unanticipated gains continue to show an asymmetry in response to gains and losses; however, households that received real unanticipated gains appear to have a significant positive offset. Similar results hold for version 4, which uses the same instruments as version 3 as well as the unemployment variables mentioned above.

Versions 1 through 4 use information known at the time of the 1984 interview to construct measures of unanticipated capital gains. As an alternative, version 5 shown in column 5 uses capital gains information from each year in the 1984-89 period to update the five-year unanticipated gains measure. Specifically, it uses the residuals from a regression of the oneyear capital gains for the 1984-85 period on the capital gains for the 1983-84 as a measure of the unanticipated gain for 1984-85, the residuals from a regression of 1985-86 gains on 198485 gains as a measure of the unanticipated gain for 1985-86, the residuals from a regression of 1986-87 gains on 1985-86 gains as a measure of the unanticipated gain for 1986-87, etc. In this manner, the one-year unanticipated capital gains can be summed for the five years from 1984-89 to form a five-year unanticipated capital gain measure for the entire 1984-89 period. The empirical estimates using version 5 indicate that for each dollar of unanticipated real capital loss, real saving increases by 13 cents. The p-value indicates that the hypothesis of symmetry can be rejected. 


\section{Conclusion}

The empirical analysis suggests that the estimated marginal propensity to consume out of real housing capital gains is 0.14 for the mean saver household and 0.03 for the median saver household. In aggregate, these results support the simulation and empirical findings of Skinner (1993). Furthermore, there is no firm evidence of a zero or positive offset as found by Hoynes and McFadden (1994). Differences in the measure of saving and the econometric methods employed may explain the divergent findings of these two studies.

The most striking finding of this paper is evidence of an asymmetry in the real saving response to both total and unanticipated real housing capital gains. The real savings offset comes from households that experience real housing capital losses. Households that experience real gains do not reduce their saving.

The existence of this asymmetry may have a number of important implications about saving in the U.S. The large run-up in real house prices in the 1970 s nationally and in the 1980 s regionally is often cited as one contributing factor in the decline in U.S. saving rates (e.g., Bosworth, Burtless, and Sabelhaus (1991)). For house prices to have power in explaining this decline in saving, there must be a robust inverse relationship between house prices and saving at the aggregate level. This aggregate relationship holds in the 1970s, but breaks down in the 1980s: although some regions of the country experienced rapid increases in real house prices in the $1980 \mathrm{~s}$, real house prices actually fell nationally in this period.

Coincident with this decline in real prices in the aggregate was a decrease, not an increase, in the U.S. saving rate. This fact alone provides prima facie evidence against a strong time- 
series link between house price appreciation and saving behavior. Moreover, the asymmetric saving response to real gains and losses found in this paper provides further evidence at the micro level against a strong inverse relationship between real house price appreciation and saving.

However, this study leaves open a number of important questions. First, while the evidence of an asymmetry in response to housing capital gains is intriguing, there is no straightforward explanation for such behavior and the result should be confirmed in other datasets. ${ }^{20}$ Second, from a theoretical standpoint, the findings of this paper and of Skinner (1993) need to be reconciled with the empirical findings on the housing and saving behavior of the elderly (e.g., Venti and Wise $(1989,1990)$ and Sheiner and Weil (1991)) in order to better understand household behavior over the life cycle.

\footnotetext{
${ }^{20}$ Shea (1993) finds evidence for an asymmetry in consumption with respect to changes in expected income which he attributes to loss aversion in preferences. In addition, Garcia, Lusardi, and $\mathrm{Ng}$ (1994) also find evidence of asymmetries in consumption behavior.
} 


\section{References}

American Chamber of Commerce Researchers Association, ACCRA Cost of Living Manual (American Chamber of Commerce Researchers Association: Arlington, VA) 1992.

Avery, Robert B. and Arthur B. Kennickell, "Household Saving in the U.S." Review of Income and Wealth 37, 1991: 409-432.

Bosworth, Barry, Gary Burtless, and John Sabelhaus, "The Decline in Saving: Some Microeconomic Evidence," Brookings Papers on Economic Activity 1, 1991: 183-256.

Bhatia, Kul, "Real Estate Assets and Consumer Spending," Quarterly Journal of Economics 1987: 437-443.

Case, Karl E. and Christopher J. Mayer, "Housing Price Dynamics Within a Metropolitan Area," Mimeo, Federal Reserve Bank of Boston, October, 1994.

Case, Karl E. and Robert J. Shiller, "The Behavior of Home Buyers in Boom and PostBoom Markets," New England Economic Review November/December, 1988: 29-46.

- "The Efficiency of the Market for Single Family Homes," American Economic Review 79, no.1, 1989: 125-137.

Engelhardt, Gary V. and Christopher J. Mayer, "Gifts for Home Purchase and Housing Market Behavior," New England Economic Review May/June, 1994: 47-58.

Garcia, Rene, Annamaria Lusardi, and Serena Ng, "Excess Sensitivity and Asymmetries in Consumption: An Empirical Investigation," Mimeo, Dartmouth College, 1994.

Goodman, John L. and John B. Ittner, "The Accuracy of Home Owners' Estimates of House Value," Journal of Housing Economics 2 (1992): 339-357.

Haurin, Donald R., Patric H. Hendershott, and Dongwook Kim, "Local House Price Indexes: 1982-1991," AREUEA Journal 19 (1991): 451-472.

Hendershott, Patric H. and Joe Peek, "Real Household Capital Gains and Wealth Accumulation," in P.H. Hendershott (ed.) The Level and Composition of Household Saving (Ballinger: Cambridge, MA) 1985a: 41-62.

-, "Household Saving: An Econometric Investigation," in P.H. Hendershott (ed.) The Level and Composition of Household Saving (Ballinger: Cambridge, MA) 1985b: 63100.

Hoynes, Hilary and Daniel McFadden, "The Impact on Demographics on Housing and NonHousing Wealth in the United States," NBER Working Paper No. 4666, March, 1994. 
Mayer, Christopher J., "Taxes, Income Distribution and the Real Estate Cycle: Why All Houses Don't Appreciate at the Same Rate," New England Economic Review 1993.

Mayer, Christopher J., and Katerina V. Simons, "The Market for Reverse Mortgages: Institutional and Household Constraints," New England Economic Review 1994.

Nakagami, Yasuhiro and Alfredo M. Pereira, "Housing Appreciation, Mortgage Interest Rates, and Homeowner Mobility," Journal of Urban Economics 30, 1991: 271-292.

Peek, Joe, "Capital Gains and Personal Saving Behavior," Journal of Money Credit and Banking 15 (February) 1983: 1-23.

Poterba, James M., "House Price Dynamics," Brookings Papers on Economic Activity 2, 1991.

Shea, John, "Union Contracts and the Life-Cycle Hypothesis," Mimeo, University of Wisconsin (forthcoming in American Economic Review), 1993.

Sheiner, Louise, "Housing Prices and the Savings of Renters," Journal of Urban Economics (forthcoming) 1995.

Sheiner, Louise, and David N. Weil, "The Housing Wealth of the Aged," Mimeo, Brown University, 1991.

Skinner, Jonathan, "A Superior Measure of Consumption from the Panel Study of Income Dynamics," Economics Letters 23, 1987: 213-216.

- - "Housing Wealth and Aggregate Saving," Regional Science and Urban Economics 19 (May) 1989: 305-324.

_ _, "Is Housing Wealth a Sideshow?," University of Virginia, mimeo, 1993.

- "Housing and Saving in the United States," in Yukio Noguchi and James M. Poterba (ed.) Housing Markets in the United States and Japan (University of Chicago Press: Chicago, IL) 1994: 191-214.

Thaler, Richard H., "Anomalies: Saving, Fungibility, and Mental Accounts," Journal of Economic Perspectives 4 (1990): 193-206.

Venti, Steven F. and David A. Wise, "Moving and Housing Expenditure: Transaction Costs and Disequilibrium," Journal of Public Economics 23 (1984): 207-243.

- - "Aging, Moving, and Housing Wealth," in David A. Wise (ed.) The Economics of Aging (University of Chicago Press: Chicago, IL) 1989: 9-48.

- , "But They Don't Want to Reduce Housing Equity," in David A. Wise (ed.) Issues in the Economics of Aging (University of Chicago Press: Chicago, IL) 1990: 13-29. 
__, "Aging and the Income Value of Housing Wealth," Journal of Public Economics 44 (1991): 371-397. 
Table 1. Sample Statistics

\begin{tabular}{|c|c|c|c|}
\hline Variable & Mean & $\begin{array}{l}\text { Standard } \\
\text { Deviation }\end{array}$ & Median \\
\hline Active Saving & 28,078 & 181,772 & 8,211 \\
\hline Active Saving Less Net Additions & 8,902 & 64,485 & 4,105 \\
\hline Net Additions & 19,176 & 163,318 & 0 \\
\hline$\Delta$ Liquid Wealth & 16,690 & 62,287 & 6,276 \\
\hline$\Delta$ Non-Housing Wealth & 62,909 & 359,676 & 10,391 \\
\hline Age & 48.8 & 9.87 & 48 \\
\hline Age Squared & 2480.8 & 956.04 & 2304 \\
\hline 1988 Income & 36,900 & 52,027 & 30,022 \\
\hline 1987 Income & 36,468 & 49,839 & 30,527 \\
\hline 1986 Income & 34,477 & 26,061 & 30,047 \\
\hline 1985 Income & 33,655 & 23,852 & 30,268 \\
\hline 1984 Income & 32,818 & 22,433 & 29,331 \\
\hline Real Housing Capital Gains & 9,701 & 52,775 & $-1,484$ \\
\hline Head Black & 0.0873 & 0.2824 & - \\
\hline Head Hispanic & 0.0328 & 0.1784 & - \\
\hline Head Married & 0.8364 & 0.3700 & - \\
\hline Head Male & 0.8687 & 0.3378 & - \\
\hline Head Has College Degree & 0.2436 & 0.4294 & 一 \\
\hline Spouse Has College Degree & 0.1438 & 0.3510 & 一 \\
\hline Change in Family Composition & 0.4843 & 0.4999 & - \\
\hline Children: Aged 1-2 & 0.1045 & 0.3363 & - \\
\hline Children: Aged 3-5 & 0.1298 & 0.3681 & - \\
\hline Children: Aged 6-13 & 0.4578 & 0.7579 & - \\
\hline Children: Aged 14-17 & 0.3082 & 0.5752 & - \\
\hline Head Self-Employed & 0.1534 & 0.3605 & - \\
\hline Spouse Self-Employed & 0.0640 & 0.2449 & - \\
\hline Head Employed & 0.9077 & 0.2895 & 一 \\
\hline Spouse Employed & 0.5232 & 0.4996 & - \\
\hline
\end{tabular}

Note: Author's tabulations based on the sample data. 
Table 2. Calculated Real Housing Appreciation for Selected States, 1984-89

\begin{tabular}{|c|c|c|c|c|}
\hline State & $\begin{array}{r}\text { Mean Real } \\
\text { Appreciation } \\
\text { (Dollars) } \\
\end{array}$ & $\begin{array}{r}\text { Mean Five } \\
\text { Year Real Rate } \\
\text { of Appreciation } \\
(\%)\end{array}$ & $\begin{array}{r}\text { Mean One } \\
\text { Year Real Rate } \\
\text { of Appreciation } \\
(\%)\end{array}$ & $\begin{array}{r}\text { Appreciation } \\
\text { As Percent of } \\
\text { Five Year Income } \\
(\%)\end{array}$ \\
\hline Alabama & $-4,065$ & -0.55 & -0.11 & -2.16 \\
\hline Arizona & $-12,101$ & -4.53 & -0.91 & -5.61 \\
\hline Arkansas & $-7,111$ & -0.48 & -0.09 & -10.98 \\
\hline California & 34,429 & 17.72 & 3.54 & 11.80 \\
\hline Colorado & $-21,310$ & -27.41 & -5.48 & -16.66 \\
\hline Connecticut & 59,895 & 70.38 & 14.07 & 29.30 \\
\hline Florida & $-13,943$ & -7.57 & -1.51 & -5.48 \\
\hline Georgia & 2,401 & 19.99 & 3.99 & 4.25 \\
\hline Mlinois & $-3,609$ & -6.50 & -1.29 & -0.16 \\
\hline Indiana & $-1,975$ & -1.77 & -0.35 & -2.06 \\
\hline Iowa & $-9,460$ & -17.15 & -3.42 & -6.90 \\
\hline Kentucky & $-5,288$ & -10.35 & -2.07 & -4.76 \\
\hline Louisiana & $-10,746$ & -17.77 & -3.55 & -10.93 \\
\hline Maryland & 24,480 & 19.99 & 3.99 & 7.79 \\
\hline Massachusetts & 77,926 & 89.66 & 17.93 & 41.14 \\
\hline Michigan & $-2,506$ & -6.81 & -1.36 & -4.63 \\
\hline Minnesota & $-14,744$ & -12.92 & -2.58 & -8.91 \\
\hline Missouri & $-4,197$ & -6.03 & -1.21 & -4.26 \\
\hline New Jersey & 75,909 & 93.12 & 18.63 & 41.44 \\
\hline New York & 56,210 & 62.83 & 12.56 & 36.41 \\
\hline North Carolina & 7,062 & 15.57 & 3.11 & 4.33 \\
\hline Ohio & 6,678 & 11.67 & 2.33 & 7.08 \\
\hline Oregon & $-14,115$ & -22.76 & -4.55 & -11.84 \\
\hline Pennsylvania & $-1,701$ & -2.51 & -0.50 & -3.04 \\
\hline South Carolina & $-4,334$ & 48.30 & 9.66 & -3.13 \\
\hline Texas & $-17,544$ & -25.19 & -5.04 & -10.58 \\
\hline Virginia & 10,696 & 10.72 & 2.14 & 6.96 \\
\hline Washington & $-13,199$ & -16.85 & -3.37 & -8.28 \\
\hline
\end{tabular}

Source: Author's tabulations based on the sample data. 
Table 3. Mean Regression Results

\begin{tabular}{|c|c|c|c|c|c|c|}
\hline $\begin{array}{l}\text { Dependent } \\
\text { Variable: }\end{array}$ & $\begin{array}{r}\text { (1) } \\
\text { Active } \\
\text { Saving } \\
\end{array}$ & $\begin{array}{r}(2) \\
\Delta \text { Non- } \\
\text { Housing } \\
\text { Wealth } \\
\end{array}$ & $\begin{array}{r}\text { (3) } \\
\text { Active } \\
\text { Saving } \\
\end{array}$ & $\begin{array}{r}\quad(4) \\
\Delta \text { Non- } \\
\text { Housing } \\
\text { Wealth }\end{array}$ & $\begin{array}{r}\quad(5) \\
\text { Active } \\
\text { Saving } \\
\end{array}$ & $\begin{array}{r}(6) \\
\Delta \text { Non- } \\
\text { Housing } \\
\text { Wealth }\end{array}$ \\
\hline $\begin{array}{l}\text { Housing } \\
\text { Capital Gains }\end{array}$ & $\begin{array}{l}-0.142 \\
(2.22)\end{array}$ & $\begin{array}{r}0.011 \\
(0.11)\end{array}$ & $\begin{array}{l}-0.136 \\
(2.13)\end{array}$ & $\begin{array}{r}0.007 \\
(0.07)\end{array}$ & $\begin{array}{l}-0.029 \\
(1.40)\end{array}$ & $\begin{array}{r}0.071 \\
(2.36)\end{array}$ \\
\hline 1988 Income & $\begin{array}{r}2.646 \\
(16.33)\end{array}$ & $\begin{array}{r}2.762 \\
(10.25)\end{array}$ & $\begin{array}{r}2.636 \\
(16.28)\end{array}$ & $\begin{array}{r}2.770 \\
(10.28)\end{array}$ & $\begin{array}{r}0.452 \\
(7.69)\end{array}$ & $\begin{array}{r}0.537 \\
(5.49)\end{array}$ \\
\hline 1987 Income & $\begin{array}{r}-3.126 \\
(17.10)\end{array}$ & $\begin{array}{r}1.829 \\
(6.02)\end{array}$ & $\begin{array}{r}-3.121 \\
(17.10)\end{array}$ & $\begin{array}{r}1.826 \\
(6.01)\end{array}$ & $\begin{array}{r}0.092 \\
(0.90)\end{array}$ & $\begin{array}{r}0.008 \\
(0.05)\end{array}$ \\
\hline 1986 Income & $\begin{array}{r}5.860 \\
(17.16)\end{array}$ & $\begin{array}{l}-0.119 \\
(0.21)\end{array}$ & $\begin{array}{r}5.865 \\
(17.20)\end{array}$ & $\begin{array}{l}-0.122 \\
(0.22)\end{array}$ & $\begin{array}{r}0.119 \\
(0.85)\end{array}$ & $\begin{array}{r}0.058 \\
(0.29)\end{array}$ \\
\hline 1985 Income & $\begin{array}{r}-3.921 \\
(14.89)\end{array}$ & $\begin{array}{r}-3.876 \\
(8.91)\end{array}$ & $\begin{array}{r}-3.908 \\
(14.94)\end{array}$ & $\begin{array}{r}-3.886 \\
(8.93)\end{array}$ & $\begin{array}{r}0.202 \\
(2.29)\end{array}$ & $\begin{array}{l}-0.105 \\
(0.87)\end{array}$ \\
\hline 1984 Income & $\begin{array}{r}2.558 \\
(7.77)\end{array}$ & $\begin{array}{r}3.846 \\
(7.03)\end{array}$ & $\begin{array}{r}2.611 \\
(7.92)\end{array}$ & $\begin{array}{r}3.805 \\
(6.94)\end{array}$ & $\begin{array}{l}-0.308 \\
(2.90)\end{array}$ & $\begin{array}{l}-0.055 \\
(0.36)\end{array}$ \\
\hline $\begin{array}{l}\text { Selection } \\
\text { Correction }\end{array}$ & - & - & $\begin{array}{r}-43387.6 \\
(2.06)\end{array}$ & $\begin{array}{r}33239.8 \\
(0.95)\end{array}$ & - & 一 \\
\hline$R^{2}$ & 0.57 & 0.56 & 0.58 & 0.56 & 0.18 & 0.13 \\
\hline $\begin{array}{l}\text { Number of } \\
\text { Observations }\end{array}$ & 1365 & 1365 & 1365 & 1365 & 1296 & 1296 \\
\hline
\end{tabular}

t-statistics in parentheses. The estimated specifications in columns 1-4 are for the full sample. Specifications in columns 5 and 6 use the $2.5 \%$ trimmed sample. All variables are expressed in real 1984 dollars. Regressors not listed in tables: age, age squared, race, gender, and marital status of the head, employment status, selfemployment, and college education for the head and spouse, and dummy variables for the ages of children and change in family composition. Estimates for the full set of regressors available upon request. 
Table 4. Median Regression Results

\begin{tabular}{|c|c|c|c|c|c|}
\hline $\begin{array}{l}\text { Dependent } \\
\text { Variable: }\end{array}$ & $\begin{array}{l}\text { Active } \\
\text { Saving } \\
\end{array}$ & $\begin{array}{r}(2) \\
\Delta \text { Non- } \\
\text { Housing } \\
\text { Wealth } \\
\end{array}$ & $\begin{array}{l}\text { Active } \\
\text { Saving } \\
\end{array}$ & $\begin{array}{l}\text { Active } \\
\text { Saving } \\
\end{array}$ & $\begin{array}{l}\text { Active } \\
\text { Saving }\end{array}$ \\
\hline $\begin{array}{l}\text { Housing } \\
\text { Capital Gains }\end{array}$ & $\begin{array}{l}-0.024 \\
(2.41)\end{array}$ & $\begin{array}{r}0.006 \\
(0.39)\end{array}$ & $\begin{array}{l}-0.042 \\
(3.76)\end{array}$ & $\longrightarrow$ & - \\
\hline $\begin{array}{l}\text { Positive Housing } \\
\text { Capital Gains }\end{array}$ & - & - & - & $\begin{array}{l}-0.008 \\
(0.45)\end{array}$ & $\begin{array}{l}-0.005 \\
(0.25)\end{array}$ \\
\hline $\begin{array}{l}\text { Negative Housing } \\
\text { Capital Gains }\end{array}$ & - & - & - & $\begin{array}{r}-0.347 \\
(14.69)\end{array}$ & $\begin{array}{l}-0.187 \\
(3.51)\end{array}$ \\
\hline $\begin{array}{l}\text { Negative Housing } \\
\text { Capital Gains*LTV }\end{array}$ & 一 & 一 & 一 & - & $\begin{array}{l}-0.597 \\
(6.14)\end{array}$ \\
\hline 1988 Income & $\begin{array}{r}0.696 \\
(28.27)\end{array}$ & $\begin{array}{r}1.250 \\
(34.33)\end{array}$ & $\begin{array}{r}0.740 \\
(28.78)\end{array}$ & $\begin{array}{r}0.743 \\
(23.84)\end{array}$ & $\begin{array}{r}0.794 \\
(24.69)\end{array}$ \\
\hline 1987 Income & $\begin{array}{r}0.161 \\
(5.88)\end{array}$ & $\begin{array}{r}0.739 \\
(16.84)\end{array}$ & $\begin{array}{r}0.184 \\
(5.90)\end{array}$ & $\begin{array}{r}0.203 \\
(5.43)\end{array}$ & $\begin{array}{r}0.165 \\
(4.23)\end{array}$ \\
\hline 1986 Income & $\begin{array}{l}-0.001 \\
(0.02)\end{array}$ & $\begin{array}{l}-0.369 \\
(4.58)\end{array}$ & $\begin{array}{r}0.052 \\
(0.88)\end{array}$ & $\begin{array}{r}0.096 \\
(1.35)\end{array}$ & $\begin{array}{r}0.089 \\
(1.20)\end{array}$ \\
\hline 1985 Income & $\begin{array}{l}-0.100 \\
(2.32)\end{array}$ & $\begin{array}{l}-0.460 \\
(8.79)\end{array}$ & $\begin{array}{l}-0.055 \\
(1.19)\end{array}$ & $\begin{array}{l}-0.043 \\
(0.79)\end{array}$ & $\begin{array}{r}-0.171 \\
(2.97)\end{array}$ \\
\hline 1984 Income & $\begin{array}{l}-0.012 \\
(0.24)\end{array}$ & $\begin{array}{l}-0.208 \\
(2.73)\end{array}$ & $\begin{array}{l}-0.157 \\
(2.76)\end{array}$ & $\begin{array}{l}-0.281 \\
(4.12)\end{array}$ & $\begin{array}{l}-0.157 \\
(2.21)\end{array}$ \\
\hline
\end{tabular}

t-statistics in parentheses. All variables are expressed in real 1984 dollars. Estimates for the full set of regressors available upon request. 
Table 4. Median Regression Results (Continued)

\begin{tabular}{|c|c|c|c|c|c|}
\hline $\begin{array}{l}\text { Dependent } \\
\text { Variable: }\end{array}$ & $\begin{array}{r}\text { (1) } \\
\text { Active } \\
\text { Saving } \\
\end{array}$ & $\begin{array}{r}(2) \\
\Delta \text { Non- } \\
\text { Housing } \\
\text { Wealth }\end{array}$ & $\begin{array}{l}\text { Active } \\
\text { Saving }\end{array}$ & $\begin{array}{l}\text { Active } \\
\text { Saving }\end{array}$ & $\begin{array}{l}\text { Active } \\
\text { Saving }\end{array}$ \\
\hline $\begin{array}{l}\text { Non-Housing } \\
\text { Capital Gains }\end{array}$ & - & 一 & $\begin{array}{r}0.024 \\
(10.36)\end{array}$ & $\begin{array}{r}0.025 \\
(9.20)\end{array}$ & $\begin{array}{r}0.025 \\
(9.01)\end{array}$ \\
\hline Inheritance & - & - & $\begin{array}{r}-0.529 \\
(21.17)\end{array}$ & $\begin{array}{r}-0.639 \\
(19.92) \\
\end{array}$ & $\begin{array}{r}-0.647 \\
(21.45) \\
\end{array}$ \\
\hline Pseudo $R^{2}$ & 0.09 & 0.08 & 0.11 & 0.12 & 0.12 \\
\hline $\begin{array}{l}\text { Number of } \\
\text { Observations }\end{array}$ & 1365 & 1365 & 1365 & 1365 & 1365 \\
\hline
\end{tabular}




\title{
Table 5. Median Regressions with Unanticipated Gains
}

Dependent Variable: Active Saving

\author{
(1) \\ (2) \\ (3) \\ (4)
}

(5)

Gains Measure:

Version 1

\begin{tabular}{|c|c|c|c|c|c|}
\hline $\begin{array}{l}\text { Unanticipated Positive } \\
\text { Housing Capital Gains }\end{array}$ & $\begin{array}{l}-0.009 \\
(0.74)\end{array}$ & $\begin{array}{r}0.017 \\
(1.53)\end{array}$ & $\begin{array}{r}0.077 \\
(2.61)\end{array}$ & $\begin{array}{r}0.086 \\
(2.89)\end{array}$ & $\begin{array}{l}-0.00 \\
(0.22)\end{array}$ \\
\hline $\begin{array}{l}\text { Unanticipated Negative } \\
\text { Housing Capital Gains }\end{array}$ & $\begin{array}{l}-0.042 \\
(3.29)\end{array}$ & $\begin{array}{l}-0.036 \\
(2.79)\end{array}$ & $\begin{array}{l}-0.105 \\
(2.33)\end{array}$ & $\begin{array}{l}-0.109 \\
(2.44)\end{array}$ & $\begin{array}{l}-0.133 \\
(4.82)\end{array}$ \\
\hline 1988 Income & $\begin{array}{r}0.839 \\
(21.48)\end{array}$ & $\begin{array}{r}0.507 \\
(10.62)\end{array}$ & $\begin{array}{r}0.491 \\
(6.63)\end{array}$ & $\begin{array}{r}0.489 \\
(6.61)\end{array}$ & $\begin{array}{r}0.805 \\
(16.34\end{array}$ \\
\hline 1987 Income & $\begin{array}{r}0.094 \\
(2.06)\end{array}$ & $\begin{array}{l}-0.262 \\
(3.83)\end{array}$ & $\begin{array}{l}-0.428 \\
(3.45)\end{array}$ & $\begin{array}{l}-0.401 \\
(3.26)\end{array}$ & $\begin{array}{r}0.11 \\
(2.02\end{array}$ \\
\hline 1986 Income & $\begin{array}{r}0.268 \\
(3.29)\end{array}$ & $\begin{array}{r}0.509 \\
(4.96)\end{array}$ & $\begin{array}{r}0.638 \\
(4.99)\end{array}$ & $\begin{array}{r}0.627 \\
(4.90)\end{array}$ & $\begin{array}{r}0.241 \\
(2.40)\end{array}$ \\
\hline 1985 Income & $\begin{array}{r}-0.136 \\
(2.23)\end{array}$ & $\begin{array}{l}-0.005 \\
(0.76)\end{array}$ & $\begin{array}{l}-0.225 \\
(1.89)\end{array}$ & $\begin{array}{l}-0.226 \\
(1.86)\end{array}$ & $\begin{array}{l}-0.075 \\
(0.99\end{array}$ \\
\hline 1984 Income & $\begin{array}{l}-0.323 \\
(4.04)\end{array}$ & $\begin{array}{l}-0.210 \\
(2.34)\end{array}$ & $\begin{array}{l}-0.086 \\
(0.77)\end{array}$ & $\begin{array}{r}0.044 \\
(0.38)\end{array}$ & $\begin{array}{l}-0.29 \\
(3.05\end{array}$ \\
\hline $\begin{array}{l}\text { Non-Housing } \\
\text { Capital Gains }\end{array}$ & $\begin{array}{r}0.029 \\
(9.98)\end{array}$ & $\begin{array}{r}0.028 \\
(11.57)\end{array}$ & $\begin{array}{r}0.026 \\
(9.85)\end{array}$ & $\begin{array}{r}0.027 \\
(9.95)\end{array}$ & $\begin{array}{r}0.032 \\
(5.52)\end{array}$ \\
\hline Inheritance & $\begin{array}{r}-0.705 \\
(17.48) \\
\end{array}$ & $\begin{array}{r}-0.998 \\
(24.93) \\
\end{array}$ & $\begin{array}{r}-1.014 \\
(22.76) \\
\end{array}$ & $\begin{array}{r}-1.020 \\
(23.00) \\
\end{array}$ & $\begin{array}{r}-0.731 \\
(14.68 \\
\end{array}$ \\
\hline $\begin{array}{l}\text { p-Value for } \\
\text { Test of Symmetry }\end{array}$ & 0.089 & 0.005 & 0.003 & 0.001 & 0.005 \\
\hline Pseudo $R^{2}$ & 0.12 & 0.11 & 0.12 & 0.12 & 0.12 \\
\hline $\begin{array}{l}\text { Number of } \\
\text { Observations }\end{array}$ & 1240 & 1001 & 794 & 777 & 1240 \\
\hline
\end{tabular}

t-statistics in parentheses. All variables are expressed in real 1984 dollars.

Estimates for the full set of regressors available upon request. 